\title{
Nectar production dynamics and daily pattern of pollinator visits in Brazil nut (Bertholletia excelsa Bonpl.) plantations in Central Amazon: implications for fruit production
}

\author{
Marcelo C. Cavalcante ${ }^{1,2}$, Leonardo Galetto ${ }^{3}$, Marcia M. Maués ${ }^{4}$, \\ Alípio José S. Pacheco Filho ${ }^{1}$, Isac Gabriel A. Bomfim ${ }^{1}$, Breno M. Freitas ${ }^{1}$ \\ ${ }^{1}$ Departamento de Zootecnia, Universidade Federal do Ceará, Avenida Mister Hull 2977, Campus do Pici, Fortaleza, CE \\ CEP 60021-970, Brazil \\ ${ }^{2}$ Universidade Federal Rural do Pernambuco, Unidade Acadêmica de Serra Talhada, Av. Gregório Ferraz Nogueira, s/n., \\ Serra Talhada, PE CEP 56909-535, Brazil \\ ${ }^{3}$ Departamento de Diversidad Biológica y Ecología e Instituto Multidisciplinário de Biologia Vegetal (UNC-CONICET), \\ Universidad Nacional de Córdoba, Casilla de Correo 495, 5000, Córdoba, Argentina \\ ${ }^{4}$ Laboratório de Entomologia, Embrapa Amazônia Oriental, Trav. Dr. Enéas Pinheiro s/n, Belém, PA 66095-903, Brazil
}

Received 23 September 2017 - Revised 8 March 2018 - Accepted 26 April 2018

\begin{abstract}
We investigated composition and secretion patterns of nectar in the Brazil nut tree (Bertholletia excelsa) and visitation patterns and glossa length of the main flower visitors along the anthesis, aiming to understand the implications for pollination and fruit production. Nectar sugar composition was dominated by sucrose and nectar secretion was continuous until 15:30 h, although flowers secreted, respectively, almost 50 and $80 \%$ of the total nectar volume and solutes in the hours immediately following flower opening, which coincides with peak flower visitation by bees. We observed a total of 19 bee species visiting the flowers to collect nectar throughout the day that can be considered pollinators. The three most abundant bee species were Xylocopa frontalis, Eufriesea flaviventris, and Eulaema mocsaryi that accounted for about $90 \%$ of the visits. In open flowers, nectar was generally scarce, encouraging bees to move among trees, and likely increasing xenogamous pollen transfer in natural habitats. However, in the large-scale Brazil nut tree plantation studied here, where genetically identical (clone) individuals are planted together in high densities, even where bees move between trees, they seem to promote functional geitonogamy, determining pollen limitation.
\end{abstract}

floral reward / foraging strategies / bee-plant interaction / pollination / reproductive success

\section{INTRODUCTION}

Nectar is one of the most important resources offered by angiosperms to potential pollinators and, although it may contain an ample variety of chemical components, three ordinary carbohydrates

Electronic supplementary material The online version of this article (https://doi.org/10.1007/s13592-018-0578-y) contains supplementary material, which is available to authorized users.

Corresponding author: M. Cavalcante, marcelufc@yahoo.com.br

Manuscript editor: Klaus Hartfelder (fructose, glucose, and sucrose) prevail in the total solutes (Stiles and Freeman 1993; Proctor et al. 1996). The production of nectar represents a costly investment of plant resources, demanding a balanced trade-off between providing sufficient quantity and quality to attract pollinators and maintain their interest in visiting other flowers, ensuring cross-pollination, but at the lowest possible cost to the plant (Devlin and Stephenson 1985). Accordingly, plants use a variety of different mechanisms to minimize the costs of nectar production, including variation in secretion patterns, sugar composition, and accessibility of nectaries (Lovett-Doust and Lovett-Doust 1988). 
Nectar secretion patterns, effects of nectar removal, and factors determining the chemical constituents of floral nectar, as well as strategies to protect the floral rewards, have been previously studied in many angiosperm species (e.g., Galetto and Bernardello 1992; Stiles and Freeman 1993; Van Wyk 1993; Torres and Galetto 1998; Navarro 1999; Bernardello et al. 1999; Goulson 1999; Galetto et al. 2000; Galetto and Bernardello 2003), because all these processes are essential to understand plant-pollinator interactions and their implications for plant reproductive success (Cruden et al. 1983; Galetto and Bernardello 1992). For example, some plant species open their flowers full of nectar (e.g., Rivera et al. 1996; Guerra et al. 2014) and others with little nectar inside (Galetto and Bernardello 1992, 1993; Amorim et al. 2013), affecting the foraging behavior of their floral visitors (Real 1981; Roubik et al. 1995). Besides that, distinct groups of floral visitors show preferences according to nectar characteristics such as sugar concentration or composition. For example, although bee-pollinated plant species usually present hexose-predominant or hexose-rich nectars in their flowers $(>75 \%$ of studied plant species), large bees (e.g., Euglossini, Centridini) prefer visiting flowers that provide sucrose-rich nectar with high sugar concentrations (35-50\%) (Roubik et al. 1995; Baker and Baker 1983; Galetto and Bernardello 2003).

Odors seem to be a secondary attractant in Neotropical species of Lecythidaceae, of which many species are bee-pollinated and produce nectar as reward (35-39\% sugar concentration and 10-60 $\mu \mathrm{L}$ /flower, depending on the species; Knudsen and Mori 1996). Floral scent compounds in nectar-rewarding Lecythidaceae could indicate that male euglossine bees may be one of the main pollinators, although this does not necessarily preclude visitation by female euglossine bees (Knudsen and Mori 1996).

Studies on Lecythidaceae nectar are rare. Potascheff et al. (2014) focused on the nectar volume and concentration of Eschweilera nana, while Freeman et al. (1991) observed that the Asiatic species Barringtonia asiatica presents nocturnal flowers which secrete nectar containing 97.6\% sucrose. Presently, there is no study on nectar of Bertholletia excelsa Bonpl., although nectar is the main reward offered by this plant species. Nectar secretion patterns and floral structures that present nectar play important roles in determining plantpollinator relationships, particularly in relation to spatio-temporal visitation patterns and the pollination efficacies of different flower visitors. Thus, a better understanding of the relationships between pollinators and flowers of Lecythidaceae, especially those only offering nectar as a reward, requires intensive study of visiting pollinator species (Knudsen and Mori 1996), their visitation patterns, and the study of temporal patterns in nectar production (e.g., volume, composition, concentration) (Galetto and Bernardello 2004, 2005).

The Brazil nut ( $B$. excelsa) is a large-sized arborous plant species which grows in Amazon forests of Brazil, Bolivia, Colombia, Guiana, Suriname, Peru, and Venezuela at a natural density of 1.3 trees/ha (Peres and Baider 1997; Wadt et al. 2005). Income generated from the harvest and natural collection of its seeds (Brazil nuts) is of paramount importance for socioeconomic development in these regions (Wadt et al. 2005). $B$. excelsa flowers are hermaphrodite and potential pollinators start to visit its flowers for nectar from the moment of their opening (Prance and Mori 2004; Santos and Absy 2012). The Brazil nut tree is predominantly xenogamous and the main pollinators are known to be large bees (Prance 1976; Mori et al. 1978; Maués 2002; Cavalcante et al. 2012). However, among the ten genera of New World Lecythidaceae, flowers of $B$. excelsa show the most complex morphologies that greatly restrict access to nectar by many flower-visiting insects (Prance 1976; Mori et al. 1978; Mori and Prance 1981; Tsou and Mori 2007; Potascheff et al. 2014). Flowers bear a chamber made of congruent staminoids that form a robust structure (hood or helmet) that covers the reproductive structures (stamens and stigma) and nectaries. $B$. excelsa produces fruits and seeds by both xenogamous and geitonogamous pollination, but under cultivation, the species suffers from severe pollen limitation (Cavalcante et al. 2012).

The aims of the present study were to determine nectar sugar composition and nectar secretion dynamics throughout the anthesis of $B$. excelsa and to record the daily frequency of flower visitors and their glossa length to better 
understand the implications for pollination success. Specifically, we obtained data on (i) nectar sugar composition of flowers from different individuals; (ii) nectar secretion dynamics during flower anthesis, considering daily variations of temperature and air humidity; and (iii) visitation patterns of the main flower visitors during the day and nectar standing crop. We discuss the behavior of the main frequent floral visitors in relation to nectar availability and the potential consequences for pollination effectiveness and plant fruit set of the Brazil nut.

\section{MATERIALS AND METHODS}

\subsection{Experimental area}

\subsubsection{Location}

The study was carried out at Aruanã farm $\left(03^{\circ}\right.$ 0'51.15" S and 58 50'13.65" W), Rodovia AM010, 215 km, Itacoatiara, Amazonas state, in Brazil, from October to December in both 2009 and 2010. The Aruanã agroindustry is the largest commercial grower of cultivated Brazil nut trees in the world. The farm has a total area of 12,000 ha out of which 3600 ha is cultivated with grafted Brazil nut trees with genetic material from eight clones, spaced by $20 \mathrm{~m} \times 20 \mathrm{~m}, 20 \mathrm{~m} \times 10 \mathrm{~m}$, or closer, $1.5 \mathrm{~m} \times 1.5 \mathrm{~m}$ in the cases of reforestation. Data collection were carried out during the blooming season from two different types of Brazil nut clones (varieties 606 and 609); trees from each clone type were concentrated in the area. Observations were performed at the top of 17-m-high wooden scaffoldings built near each studied tree.

\subsubsection{Nectar sugar composition}

Nectar samples for chemical analyses were collected at 8:00 $\mathrm{h}$ in the field from 20 bagged (non-visited flowers, bagged in bud stage) flowers from four plants (two of each type of clone) and quickly dried and stored on Whatman No. 1 chromatography paper (Galetto and Bernardello 2005). For sugar analyses, nectar was redissolved and sugar separation was accomplished by gas-liquid chromatography (GLC) to determine the types of sugar in nectar and their respective proportions (Galetto and Bernardello 2005). Nectar was lyophilized and silylated according to Sweeley et al. (1963). The derivatives were then injected into a Konik KNK 3000HRGS gas chromatograph equipped with a Spectra-Physics SP 4290 data integrator, a flame ionization detector, and a SE 30 capillary column (30 m long, $0.25 \mathrm{~mm}$ diameter, and $0.25 \mu \mathrm{m}$ thickness of the inner pellicle). Nitrogen was the carrier gas $(2 \mathrm{~mL} / \mathrm{min})$, and the following temperature program was followed: $200{ }^{\circ} \mathrm{C} / 1 \mathrm{~min}, 1^{\circ} \mathrm{C} /$ min until $208{ }^{\circ} \mathrm{C}, 10{ }^{\circ} \mathrm{C} / \mathrm{min}$ until $280{ }^{\circ} \mathrm{C}$ for 2 min. Carbohydrate standards (Sigma Chem.) were prepared using the same method.

\subsubsection{Nectar secretion pattern}

The day before anthesis, 280 flower buds were bagged with voile cloth bags in four trees to determine the volume and concentration of the floral nectar. Sampling began at 05:30 h, which was the time of the day when all flowers were already open and bees began to visit them, and carried on throughout the whole day, at 2-h intervals and from 40 flowers (10 flowers $\times 4$ plants from two clone types) at each time period, until $17: 30 \mathrm{~h}$, because after this time, most open flowers have abscised from trees.

Nectar volume was assessed using micropipettes graduated to $5 \mu \mathrm{L}$ that were carefully placed at the base of the flower staminoids for the nectar to flow up in the tube by capillary action (Hocking 1953). After that, it was necessary to lift up the hood to access drops of nectar remaining between the staminoids to ensure that all nectar was removed from the flower. Therefore, each sampling event was carried out on different flowers because after the nectar was removed the flower was destroyed. This morphological trait of the flower makes it almost impossible to study the effects of successive nectar removal on nectar production in $B$. excelsa .

Sugar concentration of sampled nectar was determined using a portable refractometer $(0-80 \%$, Atago $\left.{ }^{\circledR}\right)$, while the sugar amount per microliter of nectar was calculated using the regression equation $y=0.00226+(0.00937 x)+\left(0.0000585 x^{2}\right)$ (Dafni et al. 2005), where $x$ is the concentration and the amount of sugars in the sample (mg of 
sugar/ $\mu \mathrm{L}$ of nectar). Then, total sugar in each sample was determined by multiplying this value by the volume of nectar sampled.

Nectar traits for the standing crop data were measured from open flowers $(n=20$ flowers per seven sampling period; each sampling was separated by 2 -h interval, starting at 5:30 $\mathrm{h}$ and ending at 17:30 h) using the methods described above and according to Galetto and Bernardello (2005). The pattern of nectar available to pollinators (i.e., nectar standing crop from open flowers) was then presented in relation to the frequency of visits and compared to nectar production in bagged flowers.

The amounts of nectar per tree in volume (L) and sugar secreted $(\mathrm{kg})$ during the flowering period were estimated using the data obtained from six trees accessed via wooden scaffolding (average of $17 \mathrm{~m}$ in height). On each tree, the average number of flowering branches, inflorescences per flowering branch, and flowers per inflorescence was counted. The number of flowers per inflorescence was counted at the end of the flowering period, as previously abscised flowers left visible scars on flowering branches (Figure 1b). Based on this information, and the amount of nectar in volume $(\mu \mathrm{L})$ and sugar secreted $(\mathrm{mg})$ per flower, we estimated the total number of flowers produced per tree and the total nectar production per tree during the flowering period.

\subsubsection{Plant-pollinator interactions}

Six trees (three for each clone type) were used for the observations of bee abundance and frequency to the flowers. Scaffolds were built by the side of each tree, allowing spotting visually $60 \%$ of their canopies and access flowers for data collection. Data collection was done every hour, with two periods of $10 \mathrm{~min}$ of continuous observation, from $05: 30$ to $17: 30 \mathrm{~h}$ for 18 days (summed total of $75.6 \mathrm{~h}$ of field observations). Samples of all floral visitors were collected from each tree using entomological nets at every hour from 05:00 to 17:00 h. Then, insects were killed in a lethal chamber with ethyl acetate, pinned, identified at species level, sexed, and counted to determine their specific abundance.
To investigate bee-flower interactions and to determine which species could reach the nectar reward, we measured the glossa of visiting bee species using a digital caliper rule. A mean number of 4.3 individuals per species were killed in a death chamber containing methyl acetate. At death, bees fully extend their tongues enabling accurate measurement of tongue length. We also measured the distance from the base of the reflexed petal (hood), where the nectaries are found, to the flower opening through which the bees have access to the nectar ( $n=65$ flowers) to determine the shortest glossa length needed to succeed in collecting the nectar.

Temperature and humidity data were collected at 30-min intervals during the whole experiment using a Data Loggers $\mathrm{HOBO}{ }^{\circledR}$ placed in a shaded area of studied tree canopies.

\subsection{Statistical analyses}

The design was completely randomized. The variables studied related to nectar features (nectar volume, sugar concentration, and quantity of sugar) were tested for normality by the Shapiro-Wilk test. Since these variables did not show normality, the comparisons of these variables throughout the day (comparisons among different times) were performed using the non-parametric Kruskal-Wallis test, followed by pairwise comparison using the Mann-Whitney test.

To verify if environmental variables (temperature and humidity) were related to nectar attributes (volume, concentration, and amount of sugar), we performed a Spearman correlation test. The same test was used to investigate the relationship between the frequency of floral visitors and the nectar attributes, and between the frequency of floral visitors and environmental variables. All statistical analyses were carried out in the statistical environment $R$ (R Core Team 2017).

\section{RESULTS}

\subsection{Nectar sugar composition}

Overall nectar sugar composition in $B$. excelsa showed strong predominance by sucrose with low comparable amounts of hexoses, but with more 
glucose than fructose (Table I). Sugar proportions showed extremely low variability between sampled trees (Table I).

\subsection{Nectar secretion pattern}

Anthesis of $B$. excelsa began at $03: 30$ and by 05:00 h; all flowers were already open $(n=74)$ (Figure 1a, b). Nectar is secreted at the base of staminoids making access difficult for floral visitors with short mouthparts, therefore acting as a selective barrier to potential pollinators (Figure 1c, d). Soon after flowers opened, mean nectar volume was $14.48 \pm 1.25(\mu \mathrm{L} /$ flower $(n=$ 40 ), and a mean concentration of $38.74 \pm 0.64 \%$ $(n=40))$. Nectar production in terms of volume was continuous and increased during the day until 13:00 $\mathrm{h}$, when the peak of total sugar per flower was reached (Figure 2). There was a significant difference between time periods in nectar volume $\left(\chi^{2}=37.96, p<0.001\right)$, concentration $\left(\chi^{2}=\right.$ $141.30, p<0.001)$, and amount of sugar $\left(\chi^{2}=\right.$ $21.16, p=0.002$ ) (Figure 2). In terms of volume, the greatest value was observed at 15:30 h, although with the lowest sugar concentration. It is important to highlight that nectar concentration decreased during the day, with a minimum value of $26.80 \%$ by the end of the flower's life at 17:30 h, independently of temperature and air humidity that increased and decreased along the day, respectively (Figure 2).

Flowers secreted almost $50 \%$ of the total nectar volume and approximately $80 \%$ of the total nectar solutes in the initial $2 \mathrm{~h}$ following flower opening (Figure 2). Soon after the beginning of anthesis, the rate of nectar secretion was high $(3.76 \mu \mathrm{L} / \mathrm{h})$, but then the increase in nectar volume reduced to $0.62 \mu \mathrm{L} / \mathrm{h}$. In a second stage of high nectar secretion, in the afternoon, the rate is elevated to $4.53 \mu \mathrm{L} / \mathrm{h}$ also to be followed by a reduction to $0.97 \mu \mathrm{L} / \mathrm{h}$ (Figure 2 ). The nectar secretion pattern of $B$. excelsa was continuous and crescent-shaped until 15:30 h and increased at a rate of $2.10 \mu \mathrm{L} / \mathrm{h}$.

The peak of sugar production was earlier $(13: 30 \mathrm{~h})$ to that of maximum volume observed $(15: 30 \mathrm{~h})$ because the concentration of solutes was significantly higher $(p<0.01)$ at 13:30 than at 15:30 h (Figure 2), contributing to higher amounts of sugar in the nectar. Comparing secretion rates throughout the day, we observed that in the morning shift the mean rates of nectar secretion, both in volume and amount of sugar, increased at $1.67 \mu \mathrm{L} / \mathrm{h}$ and $0.6 \mathrm{mg}$ sugar/h, respectively. Meanwhile, in the afternoon, the mean secretion rates decreased for these parameters at $1.09 \mu \mathrm{L} / \mathrm{h}$ and $1.0 \mathrm{mg}$ sugar $/ \mathrm{h}$, respectively.

The average number of flowering branches per tree $(695.0 \pm 21.67)$ was estimated for six trees, and given that a flowering branch produced an average of $5.66 \pm 1.58$ inflorescences, with an average number of $38.07 \pm 7.54$ flowers per inflorescence, we estimated that a Brazil nut tree produces a mean of 149,758 flowers during a single flowering season. Considering also that the nectar volume and sugar concentration per flower were $26.10 \pm 14.76 \mu \mathrm{L}$ and $34.1 \pm 5.39 \%$, we calculated that a Brazil nut tree produces an average of $3.91 \mathrm{~L}$ of nectar and $1.55 \mathrm{~kg}$ of sugar during its blooming season every year.

\subsection{Plant-pollinator interactions}

During the Brazil nut blooming season, we observed a total of 19 bee species, represented by 1035 collected specimens (Table II), visiting the flowers to collect nectar throughout the day.

Table I. Nectar sugar composition of Brazil nut (Bertholletia excelsa) under cultivation, Itacoatiara, AM

\begin{tabular}{lccc}
\hline Sampled plant & Glucose (\%) & Fructose (\%) & Sucrose (\%) \\
\hline 1 & 1.67 & 0.17 & 98.16 \\
2 & 2.01 & 0.21 & 97.78 \\
3 & 1.75 & 0.19 & 98.06 \\
4 & 2.12 & 0.18 & 97.70 \\
5 & 1.58 & 0.24 & 98.18 \\
\hline
\end{tabular}




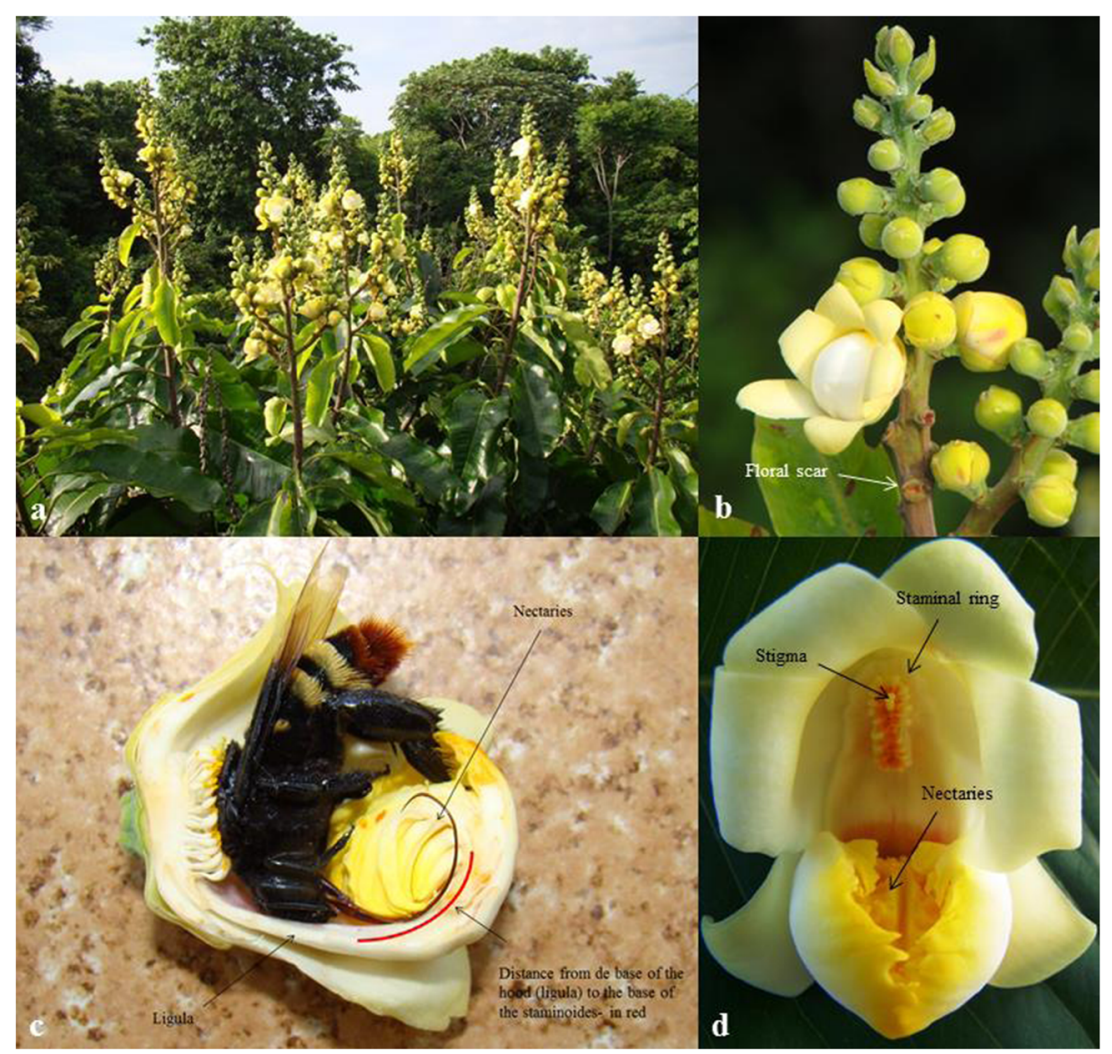

Figure 1 a Terminal inflorescences with open flowers of Bertholletia excelsa . b Close-up of inflorescence structure and floral scars. $\mathbf{c}$ Transversal cut of the Brazil nut flower showing the approach bees use to collect nectar and the distance from the base of the hood (ligula) to the base of the staminoids (in red). d Floral structures (stigma, staminal ring, and nectaries).

Visitation frequencies were highest in the morning observation period (Figure 3), when the nectar was most concentrated and air temperatures at the tree canopy were lower (Figure 2). The three most abundant bee species were Xylocopa frontalis, Eufriesea flaviventris, and Eulaema mocsaryi (with 607, 205, and 113 specimens respectively, representing 58.6, 19.8, and $10.9 \%$

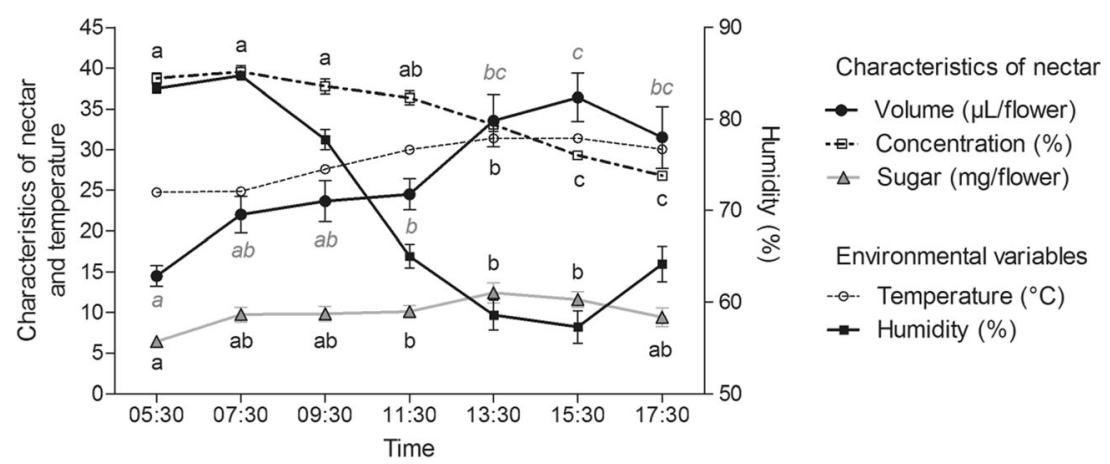

Figure 2 Pattern of nectar secretion (volume, concentration, and amount of sugar) in the cultivated Brazil nut (Bertholletia excelsa) considering environmental conditions at the canopy (temperature: ${ }^{\circ} \mathrm{C}$ and humidity: \%). 
Table II. List of families, species, sex, total abundance by sex, and relative abundance of bee flower visitors of Brazil nut (Bertholletia excelsa) under cultivation, Itacoatiara, AM

\begin{tabular}{|c|c|c|c|c|}
\hline Family & Species & Sex & $\begin{array}{l}\text { Total abundance by } \\
\text { sex }\end{array}$ & $\begin{array}{l}\text { Relative abundance } \\
(\%)\end{array}$ \\
\hline Apidae & $\begin{array}{l}\text { Xylocopa (Neoxylocopa) frontalis (Olivier, } \\
1789 \text { ) }\end{array}$ & $\hat{o}$ 우 & $12 / 595$ & 58.6 \\
\hline Apidae & Xylocopa sp. 1 & q & 6 & 0.6 \\
\hline Apidae & Xylocopa sp. 2 & q & 3 & 0.3 \\
\hline Apidae & Eufriesea flaviventris (Friese, 1899) & §ot & $25 / 180$ & 19.8 \\
\hline Apidae & Eufriesea purpurata (Mocsáry, 1896) & q & 4 & 0.4 \\
\hline Apidae & Eulaema (Apeulaema) mocsaryi (Friese, 1899) & jot & $12 / 101$ & 10.9 \\
\hline Apidae & Eulaema (Eulaema) meriana (Olivier, 1789) & j우 & $6 / 16$ & 2.1 \\
\hline Apidae & $\begin{array}{l}\text { Eulaema (Apeulaema) cingulata (Fabricius, } \\
\text { 1804) }\end{array}$ & q & 2 & 0.2 \\
\hline Apidae & $\begin{array}{l}\text { Epicharis (Epicharis) umbraculata (Fabricius, } \\
\text { 1804) }\end{array}$ & q & 3 & 0.3 \\
\hline Apidae & Epicharis (Epicharana) flava (Friese, 1900) & q & 10 & 1.0 \\
\hline Apidae & Epicharis (Epicharana) conica (Smith, 1854) & $\hat{o}$ 우 & 6 & 0.6 \\
\hline Apidae & Epicharis (Epicharana) zonata (Smith, 1874) & q & 4 & 0.4 \\
\hline Apidae & Epicharis sp. & q & 2 & 0.2 \\
\hline Apidae & $\begin{array}{l}\text { Centris (Xanthemisia) ferruginea (Lepeletier, } \\
\text { 1841) }\end{array}$ & §우 & $2 / 13$ & 1.4 \\
\hline Apidae & $\begin{array}{l}\text { Centris (Ptilotopus) denudans (Lepeletier, } \\
\text { 1841) }\end{array}$ & 주우 & $5 / 19$ & 2.3 \\
\hline Apidae & Centris (Ptilotopus) americana (Klug, 1810) & q & 2 & 0.2 \\
\hline Apidae & Centris (Trachina) longimana (Fabricius, 1804) & $\hat{o}$ & 1 & 0.1 \\
\hline Apidae & $\begin{array}{l}\text { Bombus (Fervidobombus) transversalis (Olivi- } \\
\text { er, 1789) }\end{array}$ & 우 & 2 & 0.2 \\
\hline Megachilidae & Megachile sp. 1 & q & 4 & 0.4 \\
\hline
\end{tabular}

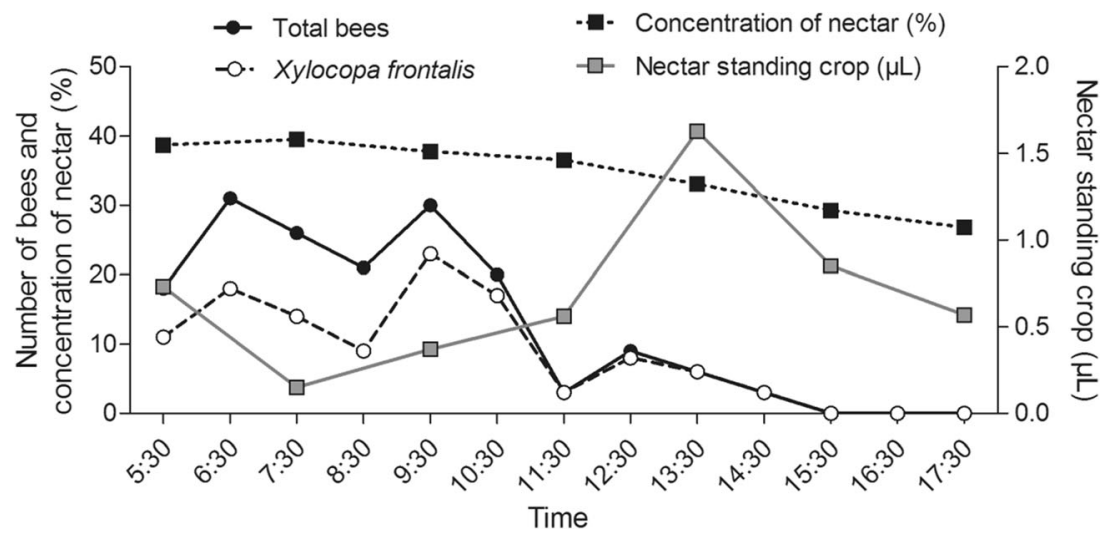

Figure 3 Mean frequency and abundance of flower visitors per tree and pattern of nectar standing crop $(\mu \mathrm{L})$ in flowers of Bertholletia excelsa open to floral visitors, Itacoatiara-Amazonas, Brazil. The scale in axis $Y$ is valid for both the bee frequency and the nectar standing $\operatorname{crop}(\mu \mathrm{L} /$ flower) which is represented by the dotted line. 
of the total number of visits observed, respectively; Table II).

Nectar available to visitors in open flowers (i.e., nectar standing crop) was generally scarce and reflected intense visitation by bees during the morning period and explained the low amount of nectar found in open flowers throughout anthesis $(<2 \mu \mathrm{L} /$ flower; Figure 3$)$. This pattern was reinforced by the sheer number of flowers showing clear visual signs of previous exploitation, as bees must force to open the external part of the corolla with their front legs to access the nectar.

We found that the total number of bees and the abundance of Xylocopa frontalis correlated strongly and positively with both the concentration of nectar in flowers and humidity, and negatively with air temperature at canopy level. In addition, the total number of bees correlated negatively with the nectar standing crop (volume) (Online Resource 1). Moreover, nectar characteristics were also significantly correlated with environmental variables (Online Resource 2).

The minimum distance from the base of the caput to the base of the staminoids (where nectar is secreted) in flowers of B. excelsa was $8.8 \mathrm{~mm}$ (Figure 1c). The measurement of the glossa length to each bee species visiting the Brazil nut flowers showed that all species, except for Megachile sp., have long enough glossa to reach the nectaries (Figure 4).

\section{DISCUSSION}

Flowers of $B$. excelsa secrete sucrose-dominant nectar mostly during daylight hours, and they are visited by many large bees. This trend corroborates with previous evidence showing that large bees prefer sucrose-rich nectar with high sugar concentrations (35-50\%) (Roubik et al. 1995; Baker and Baker 1983). In relation to the mean nectar amount and concentration produced by a flower of B. excelsa, these traits are comparable to other Lecythidacea pollinated by large bees (e.g., Potascheff et al. 2014). B. excelsa secreting almost pure sucrose nectar is one of the few examples for bee-flower pollinated species with sucrosepredominant nectars (Baker and Baker 1983; Galetto and Bernardello 2003). Thus, these initial findings for nectar sugar composition within the Lecythidaceae suggest that it seems not to be explained by pollinator guild and may be more related to phylogenetic restrictions, a trend also found in other groups of plants (e.g., Galetto et al. 1998; Perret et al. 2001; Torres and Galetto 2002).

During periods of high bee visitation frequency (i.e., early morning), almost all nectar was removed from flowers; thus, it was possible to hand collect only a small amount of nectar (minimum of $0.15 \mu \mathrm{L}$; maximum of $0.73 \mu \mathrm{L}$ ). The higher rates of visits by a great diversity of bee species to the cultivated Brazil nut trees were correlated with milder temperatures and high air humidity between 5:30 and 10:30 h, and with a high nectar production (in terms of volume, but also in concentration and total amount of solutes). In addition, during times of low bee visitation (e.g., 13:30 h), it was possible to sample small amounts of nectar (minimum of $0.57 \mu \mathrm{L}$; maximum of $1.63 \mu \mathrm{L}$;

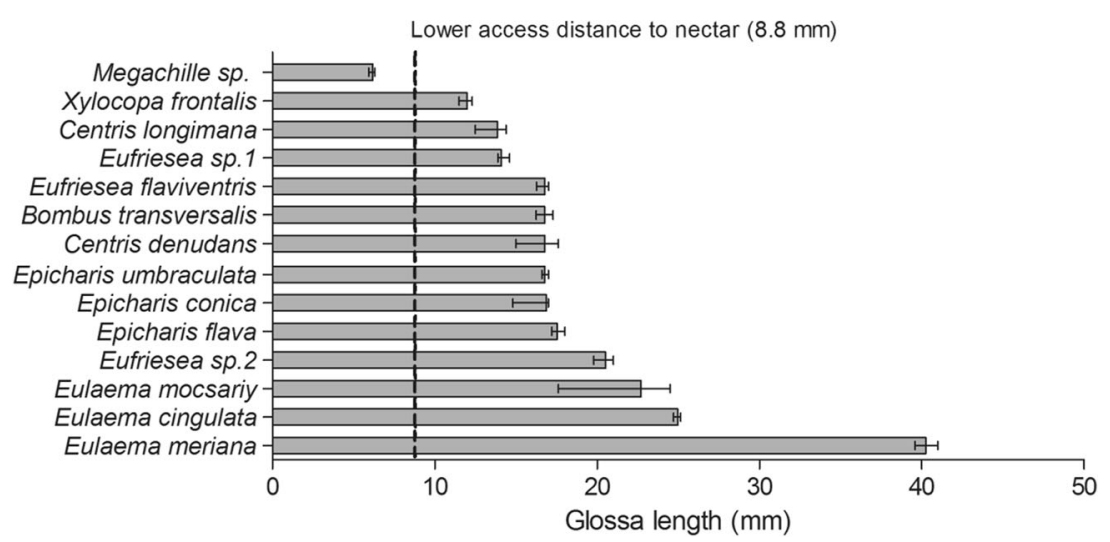

Figure 4 Average glossa length of the potential pollinators of Brazil nut (Bertholletia excelsa) cultivated in central Amazonia. 
Figure 3). However, because the production of this resource is continuous until 15:30 h, early in the afternoon, there was still little nectar available in the flowers even as the frequency and abundance of flower visitors decreased significantly in the afternoon period. Natural nectar production measured in bagged flowers showed that most nectar is removed by flower visitors and that nectar is not reabsorbed.

Many authors suggested that pollinators optimize their foraging behavior in terms of energetic costs (e.g., Zimmerman 1988; Kearns et al. 1998). In a previous study conducted within a plantation of $B$. excelsa on the Aruanã farm, in Amazonas, large bees visited flowers mainly between 5 to 10 a.m. (Santos and Absy 2010) as also found in the present study. Thus, pollinating bees seem to forage in flowers of Brazil nut optimizing the energetic costs because they are visiting flowers during morning hours, period when most nectar is secreted. An extended secretion period under natural conditions, where conspecific plant density is very low, could be related to a lower frequency of visits distributed during the entire day.

Large bees recorded here visiting flowers can be all considered pollinators of the Brazil nut. In order to access the nectar, they are forced against the stamens acquiring pollen on their head, thorax, or abdomen, and/or they are forced against the stigma depositing the pollen they carry on these parts of their bodies. Concealing floral resources in places difficult to pollinator access is a strategy adopted by many plants to restrict and select floral visitors, increasing the chances of only legitimate pollinators gaining access to the valuable floral resources. The location and arrangement of the nectaries in flowers of $B$. excelsa suggest pollinators are directed to a successful pollination touching first the stigma and then the anthers, consecutively, as attempting to reach the nectar (Prance 1976; Mori et al. 1978; Mori and Prance 1981; Tsou and Mori 2007; Potascheff et al. 2014; this work). In parallel, the sample of individual bagged flowers measured to obtain the natural nectar production pattern without bee visits showed a great variation in nectar volume. These groups of flowers sampled at the same hour of the day, presented from 3.0 to $88.0 \mu \mathrm{L}$ ( \pm 10.23 S.D.) of nectar. In hermaphrodite plants, variation in the rate of nectar production within an individual has been recognized as an adaptive characteristic that reduces the number of flowers visited per plant, reducing the time a floral visitor spends on a single plant and pollen deposition among flowers of the same individual (Pleasants 1983; Biernaskie et al. 2002).

Of the collected bee species, Eulaema meriana presented the longest glossa, exceeding $40.0 \mathrm{~mm}$. This trait may be related to the distinct foraging behavior of this species, barely penetrating the flower, and pushing its long glossa into the external floral structures to harvest the concealed nectar resources. In contrast, comparatively smaller species belonging to the genera Eufriesea, Epicharis, and Xylocopa with shorter glossas need to penetrate deep the flower to reach the nectar. Considering their abundance, frequency of visits per flower, and foraging behavior, Eulaema mocsaryi (Euglossini) and Xylocopa frontalis (Xylocopini) are most likely the two main pollinators of the Brazil nut flowers in agricultural areas of Amazonas state, corroborating Cavalcante et al. (2012) and Santos and Absy (2010).

Variations in the number of open flowers and in the nectar traits may affect the foraging behavior of the pollinator species, their pollination efficiency, and, ultimately, the economic output in terms of crop yield mainly when there is a low compatibility between individual plants like in the here studied plantation with clonal plants. It is commonly reported that the Brazil nut produces a low fruit set (Jorge and Peres 2005), and fruit production can drop significantly after a year of good reproductive success (Potascheff et al. 2014). This trend can be explained partly by considering that this species is mainly xenogamous, as shown by Cavalcante et al. (2012), and because the huge density of cloned individuals plants close to each other compared to densities within natural areas. Thus, further studies on the fruit set of wild trees versus clonal trees in plantations will be necessary to disentangle the role of bee diversity and pollen limitation in the production and management of this important crop. 


\section{ACKNOWLEDGEMENTS}

The authors thank Dr. Alistair John Campbell for the valuable contribution on manuscript review and the Agropecuária Aruanã farm for permission to carry out the studies in its premises as well as for the logistic support and use of its facilities.

\section{AUTHORS' CONTRIBUTIONS}

$\mathrm{MC}, \mathrm{MM}$ and BF conceived this research; APF and LG performed experiments and analysis; All authors participated in the interpretation of the data, wrote the paper and participated in the revisions. All authors read and approved the final manuscript.

\section{FUNDING INFORMATION}

The authors thank CAPES/Brasil for the PhD sponsorship to M.C. Cavalcante, and the Brazil nut pollination network, CNPq-Brazil (process no. 556406/2009-5), and Project Polinizadores do Brasil supported by FAO/GEF/UNEP/MMA and FUNBIO for financial support of the research. BMF was supported by CNPq-Brazil (No. 305126/2013-0) and LG thanks CONICET, FONCyT, and SECyT (UNC) for financial support.

\section{COMPLIANCE WITH ETHICAL STANDARDS}

Conflict of interest The authors declare that they have no conflict of interest.

Dynamique de la production de nectar et schéma quotidien des visites de pollinisateurs dans les plantations de noix du Brésil (Bertholletia excelsa Bonpl.) en Amazonie centrale: implications pour la production de fruits

Stratégies de récolte / Interaction abeille-plante / Pollinisation / Succès reproductif

Dynamik der Nektarproduktion und tägliche Besuche von Bestäubern auf Paranuß-Plantagen (Bertholletia excelsa Bonpl) in Zentralamazonien und deren Einfluß auf die Fruchtproduktion
Sammelstrategie / Bienen-Pflanze-Wechselwirkungen / Bestäubung / Reproduktionserfolg

\section{REFERENCES}

Amorim, F. W., Galetto, L., Sazima, M. (2013) Beyond the pollination syndrome: Nectar ecology and the role of diurnal and nocturnal pollinators in the reproductive success of Inga sessilis (Fabaceae). Plant Biol. 15(2), 317-327. https://doi.org/10.1111/j.14388677.2012.00643.x

Baker, H. G. and Baker, I. (1983) Floral nectar constituents in relation to pollinator type, in: Jones, C. E., Little, R. J. (Eds.), Handbook of experimental pollination biology. Van Nostrand Reinhold, New York, pp. 117-141.

Bernardello, G., Anderson, G. J., Lopez, S. P., Cleland, M. A., Stuessy, T. F., Crawford D. J. (1999) Reproductive biology of Lactoris fernandeziana (Lactoridaceae). Am. J. Bot. 86 (6), 829-840.

Biernaskie, J. M., Cartar, R. V., Hurly, T. A. (2002) Riskaverse inflorescence departure in hummingbirds and bumblebees: could plants benefit from variable nectar volumes? Oikos 98 (1), 98-104.

Cavalcante, M. C., Maués, M. M., Freitas, B. M. (2012) Pollination requirements and the foraging behavior of potential pollinators of cultivated Brazil nut (Bertholletia excelsa Bonpl.) trees in central Amazon rainforest. Psyche. https://doi.org/10.1155/2012 1978019.

Cruden, R. W., Herman, S. M., Peterson, S. (1983) Patterns of nectar production and plant pollination coevolution, in: Bentley, B. e Elias, T. (Eds.), The biology of nectaries, Columbia University Press, New York pp. 80 125.

Dafni, A., Kevan, P. G., Husband, B. C. (2005) Practical Pollination Biology. Enviroquest Ltd., Cambridge.

Devlin, B., Stephenson, A. G. (1985) Sex differential floral longevity, nectar secretion, and pollinator foraging in a protandrous species. Am. J. Bot. 72 (2), 303-310.

Freeman, C. E., Worthington, R. D., Jackson, M. S. (1991) Floral nectar sugar compositions of some South and Southeast Asian species. Biotropica. https://doi. org/10.2307/2388394.

Galetto, L., Bernardello, L. M. (1992) Extrafloral nectaries that attract ants in Bromeliaceae: structure and nectar composition. Can. J. Bot. https://doi.org/10.1139/b92136.

Galetto, L., Bernardello, L. M. (1993) Nectar secretion pattern and removal effects in three Solanaceae. Can. J. Bot. https://doi.org/10.1139/b93-167.

Galetto, L., Bernardello, G. (2003) Nectar sugar composition in angiosperms from Chaco and Patagonia (Argentina): An animal visitor's matter? Plant Syst. Evol. https://doi.org/10.1007/s00606-002-0269-y.

Galetto, L., Bernardello, G. (2004) Floral nectaries, nectar production dynamics and chemical composition in six 
Ipomoea species (Convolvulaceae) in relation to pollinators. Ann. Bot. https://doi.org/10.1093 /aob/mch137.

Galetto, L., Bernardello, G. (2005). Rewards in flowers: nectar, in: Dafni, A., Kevan P. G. and Husband, B. C. (Eds.), Practical Pollination Biology. Enviroquest Ltd., Cambridge, pp. 261-313.

Galetto, L., Bernardello, G., Sosa, C.A. (1998) The relationship between floral nectar composition and visitors in Lycium (Solanaceae) from Argentina and Chile: what does it reflect? Flora. https://doi.org/10.1016 /S0367-2530(17)30851-4.

Galetto, L., Bernardello, G., Isele, I. C., Vesprini, J., Speroni, G., Berduc, A. (2000) Reproductive biology of Erythrina crista-galli (Fabaceae). Ann. Mo. Bot. Gard. 87 (2), 127-145.

Goulson, D. (1999) Foraging strategies of insects for gathering nectar and pollen, and implications for plant ecology and evolution. Perspect. Plant Ecol. Evol. Syst. https://doi.org/10.1078/1433-8319-00070.

Guerra, T. J., Galetto, L., Silva, W. R. (2014) Nectar secretion dynamic links pollinator behavior to consequences for plant reproductive success in the ornithophilous mistletoe Psittacanthus robustus. Plant Biol. https://doi.org/10.1111/plb.1214616.

Hocking, B. (1953) The intrinsic range and speed of flight of insects. Trans. R. Entomol. Soc. Lond. 104, pt. 8, 223-345.

Jorge, M. S. P., Peres, C. A. (2005) Population density and home range size of Red-Rumped Agoutis (Dasyprocta leporina ) within and outside a natural Brazil nut stand in Southeastern Amazonia. Biotropica. https://doi. org/10.1111/j.1744-7429.2005.00041.x.

Kearns, C. A., Inouye, D. W., Waser N. (1998) Endangered mutualisms: the conservation of plant-pollinator interactions. Annu. Rev. Ecol. Syst. https://doi.org/10.1146 /annurev.ecolsys.29.1.83.

Knudsen, J. T., Mori, S. A. (1996) Floral scents and pollination in Neotropical Lecythidaceae. Biotropica. https://doi.org/10.2307/2388770.

Lovett-Doust, J., Lovett-Doust, L. (1988) Plant reproductive ecology: patterns and process. Oxford University Press, Oxford.

Maués, M. M. (2002) Reproductive phenology and pollination of the Brazil nut tree (Bertholletia excelsa Humb.e Bonpl.) in eastern Amazonia, in: Kevan, P. G. and Imperatriz Fonseca, V. L. (Eds.) Pollinating Bees: the conservation link between agriculture and nature. Ministry of Environment, Brasília, pp. 245254.

Mori, S. A., Prance, G. T. (1981) Relações entre a classificação genérica de Lecythidaceae do Novo Mundo e seus polinizadores e dispersadores. Rev. Bras. Bot. 4, 31-37.

Mori, S. A., Prance, G. T., Bolten, A. B. (1978) Additional notes on the floral biology of Neotropical Lecythidaceae. Brittonia, 30(02), 113-130.
Navarro, L. (1999) Pollination ecology and effect of nectar removal in Macleania bullata (Ericaceae). Biotropica. https://doi.org/10.1111/j.1744-7429.1999.tb00410.x.

Peres, C. A., Baider, C. (1997) Seed dispersal, spatial distribution and population structure of Brazilnut trees (Bertholletia excelsa) in southeastern Amazonia. J. Trop. Ecol. https://doi.org/10.1017 /S0266467400010749.

Perret, M., Chautems, A., Spichiger, R., Peixoto, M., Savolainen, V. (2001) Nectar sugar composition in relation to pollination syndromes in Sinningieae (Gesneriaceae). Ann. Bot. https://doi.org/10.1006 /anbo.2000.133.

Pleasants, J. M. (1983) Nectar production patterns in Ipomopsis addredata (Polemoniaceae). Am. J. Bot. 70, 1468-1475.

Potascheff, C. M., Mori, S. A., Lombardi, J. A. (2014) Pollination ecology of the Cerrado species Eschweilera nana (Lecythidaceae subfam. Lecythidoideae). Brittonia. https://doi.org/10.1007/s12228-013-9314-0.

Prance, G. T. (1976) The pollination and androphore structure of some Amazonian Lecythidaceae. Biotropica. https://doi.org/10.2307/2989715.

Prance, G. T., Mori, S. A. (2004) Lecythidaceae, in: Kubitzki, K. and Bayer, C. (Ed.), The families and genera of vascular plants. Springer-Verlag, Berlin, pp. 221-232.

Proctor, M., Yeo, P., Lack, A. (1996) The natural history of pollination. Timber Press, Portland.

R Core Team (2017) R: A Language and Environment for Statistical Computing. R Foundation for Statistical Computing, Vienna, Austria.

Real, L. A. (1981) Nectar availability and bee-foraging on Ipomoea (Convolvulaceae). Biotropica 13 (2), 64-69.

Rivera, G. L., Galetto, L., Bernardello, L. (1996) Nectar secretion pattern, removal effects, and breeding system of Ligaria cuneifolia (Loranthaceae). Can. J. Bot. https://doi.org/10.1139/b96-239.

Roubik D. W., Yanega D., Aluja S. M., Buchmann S. L., Inouye D. W. (1995) On optimal nectar foraging by some tropical bees (Hymenoptera: Apidae). Apidologie. https://doi.org/10.1051/apido:19950303.

SANTOS, C.F. and ABSY, M.L. (2010) Polinizadores de Bertholletia excelsa (Lecythidales: Lecythidaceae): interações com abelhas sem ferrão (Apidae: Meliponini) e nicho trófico. Neotropical Entomology, 39(6):854-861.

Santos, C. F., Absy, M. L. (2012) Interactions between carpenter bees and orchid bees (Hymenoptera: Apidae) in flowers of Bertholletia excelsa Bonpl. (Lecythidaceae) Acta Amaz. https://doi.org/10.1590 /S0044-59672012000100011.

Stiles, F. G, Freeman, C. E. (1993) Patterns in floral nectar characteristics of some bird-visited plant species from Costa Rica. Biotropica. https://doi.org/10.2307 /2389183.

Sweeley, C. C., Bentley, R., Makita, M., Wells, W. W. (1963) Gas liquid chromatography of trimethylsilyl 
derivatives of sugars and related substances. J. Am. Chem. Soc. https://doi.org/10.1021/ja00899a032.

Torres, C., Galetto, L. (1998) Patterns and implications of floral nectar secretion, chemical composition, removal effects and standing crop in Mandevilla pentlandiana (Apocynaceae). Bot. J. Linn. Soc. https://doi. org/10.1111/j.1095-8339.1998.tb02098.x

Torres, C., Galetto, L. (2002) Are nectar sugar composition and corolla tube length related to the diversity of insects that visit Asteraceae flowers? Plant Biol. https://doi.org/10.1055/s-2002-32326.

Tsou, C., Mori, S. A. (2007) Floral organogenesis and floral evolution of the Lecythidoideae (Lecythidaceae). Am. J. Bot. https://doi.org/10.3732/ajb.94.5.716.
Van Wyk, B. E. (1993) Nectar sugar composition in southern African Papilionoideae (Fabaceae). Biochem. Syst. Ecol. https://doi.org/10.1016/0305-1978(93)90045-S

Wadt, L. H. O., Kainer, K. A., Gomes-Silva, D. A. P. (2005) Population structure and nut yield of a Bertholletia excelsa stand in Southwestern Amazonia. For. Ecol. Manag. https://doi.org/10.1016/j.foreco.2005.02.061

Zimmerman, M. (1988) Nectar production, flowering phenology and strategies for pollination, in: Lovett-Doust, J., Lovett-Doust, L. (Eds.), Plant reproductive ecology: patterns and strategies. Oxford Univ. Press, Oxford, pp. $157-178$. 